\title{
Development of GABA Circuitry of Fast-Spiking Basket Interneurons in the Medial Prefrontal Cortex of erbb4-Mutant Mice
}

\author{
Jian-Ming Yang (杨建明), ${ }^{1 *}$ Jing Zhang (张晶), ${ }^{1 *}$ Xiao-Juan Chen (陈晓娟), ${ }^{1}$ Hong-Yan Geng (耿红岩), ${ }^{1}$ \\ Mao Ye (叶茂), ${ }^{1}$ Nicholas C. Spitzer, ${ }^{2}$ Jian-Hong Luo (罗建红), ${ }^{1,3}$ Shu-Min Duan (段树民), ${ }^{1,3}$ \\ and Xiao-Ming Li (李晓明) ${ }^{1,3}$ \\ ${ }^{1}$ Institute of Neuroscience, Key Laboratory of Medical Neurobiology of the Ministry of Health, Zhejiang Province Key Laboratory of Neurobiology, Zhejiang \\ University School of Medicine, Hangzhou, Zhejiang, China, 310058, ${ }^{2}$ Neurobiology Section, Division of Biological Sciences and Center for Neural Circuits \\ and Behavior, University of California, San Diego, La Jolla, California 92093-0357, and ${ }^{3}$ Soft Matter Research Center, Zhejiang University, Hangzhou, \\ Zhejiang, China, 310058
}

erbb4 is a susceptibility gene for schizophrenia and ErbB4 signals have been hypothesized to function in a number of cortical developmental processes (Silberberg et al., 2006; Mei and Xiong, 2008). Several recent studies show that the expression of ErbB4 is mainly restricted to GABAergic interneurons (Yau et al., 2003; Woo et al., 2007), specifically, to parvalbumin-positive (PV) fast-spiking (FS) interneurons (Vullhorst et al., 2009; Fazzari et al., 2010), a large majority of which are PV FS basket cells (Kawaguchi, 1995; Taniguchi et al., 2013). However, in the medial prefrontal cortex (mPFC), a brain region that is closely associated with neuropsychiatric disorders including schizophrenia, little is known about the roles of ErbB4 signals during the development of GABAergic circuitry particularly that associated with PV FS basket cells. Here, using molecular genetics, biochemistry, and electrophysiology, we deleted ErbB4 receptors in GABAergic forebrain neurons during the embryonic period and demonstrated that in the mouse MPFC, ErbB4 signals were dispensable for the development of GABAergic synapses by PV FS basket cells. Interestingly, they were required for the final maturation rather than the initial formation of glutamatergic synapses on PV FS basket cells. Furthermore, activity-dependent GABAergic PV FS pyramidal neuron transmission was decreased, whereas activity of pyramidal neurons was increased in KO mice. Together, these data indicate that ErbB4 signals contribute to the development of GABAergic circuitry associated with FS basket cells in component- and stage-dependent manners in the mPFC in vivo, and may suggest a mechanism for neuropsychiatric disorders including schizophrenia.

Key words: development; medial prefrontal cortex (mPFC); ErbB4; parvalbumin (PV) interneurons; GABAergic circuitry; schizophrenia

\section{Introduction}

erbb4 is a susceptibility gene for schizophrenia and ErbB4 signals are hypothesized to play a pivotal role in mediating diverse neural developmental processes ranging from neural proliferation and migration to neurite growth and synapse

\footnotetext{
Received April 15, 2013; revised 0ct. 27, 2013; accepted Nov. 7, 2013.

Author contributions: J.-M.Y., J.Z., and X.-M.L. designed research; J.-M.Y., J.Z., X.-J.C., H.-Y.G., and M.Y. performed research; N.C.S., J.-H.L., S.-M.D., and X.-M.L. contributed unpublished reagents/analytic tools; J.-M.Y. and J.Z. analyzed data; J.-M.Y. and X.-M. L. wrote the paper.

This work was supported by grants from China National Funds for Distinguished Young Scientists (81225007), the National Basic Research Program of China (973 Program, 2010 (B912004), the National Natural Science Foundation of China (91132714, 30970916, and 31070926), the Zhejiang Provincial Natural Science Foundation of China (Z2090127), the Funds for Creative Research Groups of China (81221003), PCSIRT, the Fundamental Research Funds for the Central Universities (2011XZZX002), the Zhejiang Province Key Technology Innovation Team (2010R50049), Zhejiang Provincial Program for the Cultivation of High-level Innovative Health talents, and the 111 Project (B13026) to X.-M.L. We thank Dr. Josh Huang (Cold Spring Harbor Laboratory, Cold Spring Harbor, NY) and Dr. X.H. Zhang (Beijing Normal University, Beijing, China) for kindly providing the G42 mice, Dr. T.M. Gao and Dr. L. Mei for insightful suggestions, and Dr. I.C. Bruce for critically reading the paper.

The authors declare no competing financial interests.

*J.-M.Y. and J.Z. contributed equally to this work.

Correspondence should be addressed to Xiao-Ming Li, Zhejiang University School of Medicine, 866 Yuhangtang Road, Research Building, Room A507, Hangzhou, Zhejiang, China 310058. E-mail: lixm@zju.edu.cn.

DOI:10.1523/JNEUROSCI.1584-13.2013

Copyright $\odot 2013$ the authors $\quad 0270-6474 / 13 / 3319724-10 \$ 15.00 / 0$
}

formation (Silberberg et al., 2006; Mei and Xiong, 2008). The expression of ErbB4 during the embryonic period (Yau et al., 2003; Flames et al., 2004) and the colocalization of ErbB4 with PSD-95 (Garcia et al., 2000; Huang et al., 2000) have led to the hypothesis that ErbB4 signaling is involved in the development of cortical excitatory circuitry (Gu et al., 2005; Li et al., 2007; Barros et al., 2009). However, recent work demonstrates that interneurons, particularly parvalbumin-positive (PV) fast-spiking (FS) interneurons, are the major neuronal subtype in the neocortex that expresses ErbB4 (Woo et al., 2007; Vullhorst et al., 2009; Fazzari et al., 2010; Neddens et al., 2011). Thus, much attention has been focused on evidence supporting a role for ErbB4 signaling in the development of cortical GABAergic circuitry (Abe et al., 2011; Ting et al., 2011), particularly that associated with PV-positive chandelier cells (Fazzari et al., 2010; Marín, 2012), a minor subtype of PV FS interneurons [ $\sim 15 \%$ of chandelier FS neurons express PV in the medial prefrontal cortex (mPFC; Taniguchi et al., 2013)]. Although it is widely regarded that both chandelier and basket cells constitute PV FS interneurons in the neocortex, the latter accounts for a large majority of PV FS interneurons (Kawaguchi, 1995; Taniguchi et al., 2013) and are a major source of ErbB4 expression both during early development and in adult life. However, it is largely unknown what role(s) 
ErbB4 signaling plays during the development of GABAergic circuitry associated with PV FS basket cells in the mPFC, which are involved in many developmental neuropsychiatric disorders, such as schizophrenia (Callicott et al., 2003).

To study the functions of ErbB4 signaling in the postnatal development of interneurons, PV FS basket cells in particular, in the PFC in vivo, we genetically deleted ErbB4 receptors in GABAergic forebrain neurons during the embryonic period. Contrary to our expectations, we found that ablation of ErbB4 exerted no significant influence on the layered structure of the neocortex nor on the laminar distribution of PV interneurons in the PFC. More importantly, the development of GABAergic synapses by FS basket cells was largely undisturbed. Interestingly, although the initial formation of glutamatergic synapses on PV FS basket cells was unaltered, the maturation of these synapses was impaired in the absence of ErbB4 signaling. Furthermore, activity-dependent GABAergic PV FS-pyramidal neuron (PN) transmission was decreased, whereas activity of PNs was increased in $\mathrm{KO}$ mice. Together, these data suggest that ErbB4 signals contribute to the development of FS basket cell-mediated GABA inhibition in component- and stage-dependent manners in the $\mathrm{mPFC}$ in vivo, and may suggest a mechanism for abnormal GABA circuitry development in neuropsychiatric disorders including schizophrenia (Lewis et al., 2005).

\section{Materials and Methods}

Animals. Two mouse lines were used. First, the Dlx5/6-Cre;erbb $4^{f l / f l}$ (Dlx5/6-erbb4 ${ }^{-1-}$ ) line was generated by crossing Dlx5/6-Cre mice (The Jackson Laboratory) with erbb4 $4^{f l f l}$ mice (Mutant Mouse Regional Resource Center). A second line was obtained by crossing Dlx5/6-erbb4 ${ }^{-1-}$ mice with G42 mice that express EGFP in PV-expressing FS interneurons (kindly provided by Z. Josh Huang, Cold Spring Harbor Laboratory, Cold Spring Harbor, NY, and Dr. Xiao-Hui Zhang, Institute of Neuroscience, Beijing, China). Littermates carrying either the CRE gene (Dlx5/


wild-type mice in terms of newborn survival rate, general health, such as fur color, appetite, and body weight, and were used as controls. Mice were housed under a $12 \mathrm{~h}$ light/dark cycle and had access to food and water ad libitum. Only male mice were used. All animal use procedures were reviewed and approved by the Animal Advisory Committee at Zhejiang University following the National Institutes of Health Guidelines for the Care and Use of Laboratory Animals.

Western analysis. Protein samples were run on 10\% SDS-polyacrylamide gels, and then transferred to polyvinylidene difluoride membranes. After blocking in 3\% nonfat milk for $1 \mathrm{~h}$ at room temperature (RT), membranes were incubated with the respective primary antibodies at $4^{\circ} \mathrm{C}$ overnight (rabbit anti-ErbB4, 1:4000, Abcam; rabbit anti-ErbB2, 1:100, Abcam; goat anti-gephyrin, 1:500, Santa Cruz Biotechnology; mouse anti-GAD65/67, 1:200, Santa Cruz Biotechnology; rabbit anti$\mathrm{GABA}_{\mathrm{A}} \alpha 1 / \alpha 2,1: 1000$, Abcam; rabbit anti-GABA $\beta 2,1: 2000$, Abcam; rabbit anti-Akt, 1:2000, Cell Signaling Technology; goat anti-GAPDH, 1:2000, Santa Cruz Biotechnology; rabbit anti- $\beta$-actin, 1:1000, Cell Signaling Technology; rabbit anti-Cx36, 1:200, Invitrogen). After washing three times in $0.1 \%$ Tween 20 in TBS, the membranes were incubated with horseradish peroxidase-conjugated secondary antibodies in 3\% nonfat milk for $1 \mathrm{~h}$ at RT and visualized with an ECL kit (Thermo Scientific). Quantitative analysis was performed with NIH ImageJ software. Each experiment was performed at least three times. Data used for statistical analyses were from $\geq 6$ mice each group.

Immunohistochemistry. After deep anesthesia, mice were perfused with ice-cold saline followed by $4 \%$ paraformaldehyde (PFA) in $0.1 \mathrm{M} \mathrm{PBS,} \mathrm{pH}$ 7.4. The brains were removed, postfixed overnight in $4 \% \mathrm{PFA}$ at $4^{\circ} \mathrm{C}$, and transferred to $30 \%$ sucrose in $0.1 \mathrm{M}$ PBS, pH 7.4. Coronal sections (50 $\mu \mathrm{m}$ ) were cut on a cryostat (Leica CM3050 S). After washing three times in $0.5 \%$ Triton X-100 in PBS (PBST), the sections were incubated in blocking buffer containing 3\% bovine serum albumin and 5\% normal goat serum in PBST for $1 \mathrm{~h}$ at RT, and then with primary antibodies in blocking buffer overnight at $4^{\circ} \mathrm{C}$ (mouse anti-ErbB4, 1:500, Abcam; guinea pig anti- ${ }_{V} G A T, 1: 500$, Synaptic Systems; mouse anti-parvalbumin, 1:5000, Swant; rabbit anti-NeuN, 1:500, Millipore; rabbit anti-vGluT1, 1:1000, Abcam; rabbit anti-Cx36, 1:200, Invitrogen). After washing three times with PBST, the sections were incubated with Alexa Fluor 488- or Alexa Fluor 543-conjucted secondary antibodies at RT for $1 \mathrm{~h}$. After another three wash cycles in PBST, sections were mounted with Pro-long anti-fade medium (Invitrogen). Although NeuN is considered to be a pan-neuronal marker, under our experimental conditions, we discovered only occasional colocalization of NeuN with GAD67 in the PFC (data not shown), possibly due to the low expression level of $\mathrm{NeuN}$ in GABAergic neurons being below the detection limit with our method; thus strongly NeuN-positive neurons with a typical pyramidal morphology were regarded as pyramidal neurons.

Analysis of perisomatic synapse formation. Images from a single confocal plane were captured in layers V/VI in the PFC with a $60 \times$ oilimmersion objective (NA 1.4) using an inverted confocal microscope (Olympus FV1000). A stack of three images beginning at the surface of the neuron was captured by $z$-axis scanning at $1 \mu \mathrm{m}$ intervals for each neuron. The second image was used for data analysis. All images were acquired using the same parameters. vGAT, PV, and vGluT1 puncta $(<2$ $\mu \mathrm{m}$ away from the soma membrane; $10-80$ pixels) were counted using $\mathrm{NIH}$ ImageJ software. The image capture and analysis were done by investigators blind to the genotype.

Preparation of in vitro brain slices. Mice were deeply anesthetized and decapitated. The brain was quickly removed and placed in ice-cold artificial CSF (ACSF) consisting of (in mM): $125 \mathrm{NaCl}, 2.5 \mathrm{KCl}, 11 \mathrm{D}$-glucose, $26 \mathrm{NaHCO}_{3}, 1.25 \mathrm{NaH}_{2} \mathrm{PO}_{4}, 2 \mathrm{CaCl}_{2}$, and $2 \mathrm{MgCl}_{2}$. The solution was bubbled with $95 \% \mathrm{O}_{2} / 5 \% \mathrm{CO}_{2}$ to maintain a $\mathrm{pH} \sim 7.4$. Coronal slices $(300 \mu \mathrm{m})$ containing PFC were cut on a microtome (Leica VT1000S). The slices were stored for $30-45 \mathrm{~min}$ at $37^{\circ} \mathrm{C}$ in oxygenated ACSF, and then kept at RT.

Electrophysiology. Whole-cell recordings were done in the medial prefrontal cortex including the prelimbic, infralimbic, and anterior cingulate cortices. Fluorescent cells were visually identified under an upright microscope (Nikon, Eclipse FN1) equipped with a $40 \times$ waterimmersion lens and infrared differential interference contrast optics and illuminated with a mercury lamp. Individual slices were transferred to a recording chamber and fully submerged in continuously perfused $(\sim 2$ $\mathrm{ml} / \mathrm{min}$ ) with oxygenated ACSF maintained at $34 \pm 2{ }^{\circ} \mathrm{C}$. EGFPexpressing FS basket interneurons were identified based on two criteria: the presence of multipolar dendritic trees lacking apparent apical and/or basal dendrites, and a round/oval shape and soma diameter $>10 \mu \mathrm{m}$. For paired recordings, microelectrodes (2.5-4.5 $\mathrm{M} \Omega$ ) were filled with (in mM): $110 \mathrm{~K}$-gluconate, $40 \mathrm{KCl}, 10 \mathrm{HEPES}, 2 \mathrm{Mg}$-ATP, $0.5 \mathrm{Na}_{3}$-GTP, and 0.2 EGTA; pH was adjusted to 7.25 with $10 \mathrm{M} \mathrm{KOH}$. For mIPSC and sIPSC recordings, we used a pipette solution containing the following (in $\mathrm{mm}$ ): $130 \mathrm{CsCl}, 4 \mathrm{NaCl}, 10$ tetraethylammonium (TEA), 10 HEPES, 2 $\mathrm{Na}_{2}$-ATP, $0.5 \mathrm{Na}_{3}$-GTP, and 0.2 EGTA; $\mathrm{pH}$ was adjusted to 7.25 with 10 $\mathrm{M} \mathrm{CsOH}$; when recording mEPSCs, $\mathrm{CsCl}$ was substituted by $130 \mathrm{~mm}$ $\mathrm{CsMeSO}_{3}$. For paired recordings, we simultaneously recorded from two EGFP-positive cells ( $<100 \mu \mathrm{m}$ apart) or one EGFP-expressing cell and one pyramidal neuron $(<20 \mu \mathrm{m}$ apart) from layers V/VI in the PFC. Kynurenic acid ( $>2 \mathrm{~mm}$, Sigma-Aldrich; to block glutamatergic transmissions) and mefloquine (50 $\mu \mathrm{M}$, Sigma-Aldrich; to block gap junctional connections) were added in the bath solution when studying chemical synaptic connections between FS interneurons (Yang et al., 2012). Most FS interneurons are interconnected by both electrical and GABAergic synapses, and the low-pass filtering properties of gap junctions enable them to transmit signals at low-frequency, such as afterhyperpolarization (AHP) more efficiently (Bennett and Zukin, 2004); thus, postsynaptic responses mediated by both synaptic types tend to overlap, leading to the distortion of pure GABAergic responses (Yang et al., 2012, their supplemental Fig. 2). Thus, to analyze the properties of unitary IPSCs (uIPSCs) among FS basket cells, mefloquine $(50 \mu \mathrm{M})$ was present in the bath solution throughout experiments. To isolate miniature IPSCs (mIPSCs), tetrodotoxin (TTX; $1 \mu \mathrm{M}$, to block sodium current), DL-2amino-5-phosphonopentanoic acid (AP-V; $50 \mu \mathrm{M}$, Tocris Bioscience, to block NMDA receptors), and 6, 7-dinitroquinoxaline-2, $3(1 \mathrm{H}, 4 \mathrm{H})$ dione (DNQX; $20 \mu \mathrm{M}$, Tocris Bioscience, to block AMPA receptors) were 
present in the bath solution. Spontaneous IPSCs (sIPSCs) were recorded in the presence of AP-V $(50 \mu \mathrm{M})$ and DNQX $(20 \mu \mathrm{M})$. To isolate mEPSCs, TTX $(1 \mu \mathrm{M})$ and picrotoxin $\left(50 \mu \mathrm{M}\right.$, Sigma-Aldrich, to block $\mathrm{GABA}_{\mathrm{A}}$ receptors) were added in the bath solution. Recordings were started 2-3 min after a stable whole-cell configuration was obtained. Access resistance $(R \mathrm{a} ;<20 \mathrm{M} \Omega)$ was not compensated and was continually monitored throughout each experiment. Recordings were terminated whenever input resistance increased $>30 \%$ or access resistance exceeded $20 \mathrm{M} \Omega$. To detect chemical synaptic transmission, the presynaptic neuron was held in the current-clamp mode near the resting membrane potential (RMP) and stimulated at a frequency of $0.5 \mathrm{~Hz}$. Action potentials (APs) were generated by brief current pulses (duration, $2 \mathrm{~ms}$; amplitude, $2 \mathrm{nA}$ ). The postsynaptic cell was held in the voltage-clamp mode (holding potential, $-70 \mathrm{mV}$ ). IPSCs and EPSCs under these conditions are inward. For mIPSC, sIPSC, and mEPSC recordings, neurons were voltage-clamped at $-70 \mathrm{mV}$. To evoke excitatory synaptic responses on FS cells, a concentric bipolar electrode was placed $\sim 50 \mu \mathrm{m}$ laterally away, and the stimulus intensity (single pulse, $0.1 \mathrm{~ms}, 40-500 \mu \mathrm{A}, 0.1 \mathrm{~Hz}$ ) was carefully adjusted to produce an AMPA receptor-mediated current $\left(\mathrm{eEPSC}_{\mathrm{AM}^{-}}\right.$ PAR) of $\sim 200 \mathrm{pA}$ at $-70 \mathrm{mV}$ in the presence of picrotoxin (50 $\mu \mathrm{M}$, SigmaAldrich). Peak amplitude for eEPSC $_{\text {AMPAR }}$ was measured at $-70 \mathrm{mV}$. NMDAR-mediated currents $\left(\right.$ eEPSC $_{\text {NMDAR }}$ ) were recorded at +50 $\mathrm{mV}$. The amplitude of eEPSC $\mathrm{NMDAR}_{\text {was mea- }}$ sured $50 \mathrm{~ms}$ after the elicited synaptic current at $+50 \mathrm{mV}$ and was confirmed by bath application of the NMDAR antagonist AP-V (50 $\mu \mathrm{M})$. Spontaneous firing rates of FS neurons were recorded extracellularly in a modified $\operatorname{ACSF}\left(5 \mathrm{~mm} \mathrm{KCl}, 0.5 \mathrm{~mm} \mathrm{MgSO}_{4}, 1 \mathrm{~mm} \mathrm{CaCl}_{2}\right.$; Wen et al., 2010) in a tight-seal cell-attached configuration (0.3-1 G $\Omega$ ) with the pipettes filled with the same solution used for paired recording, and fast-spiking properties were confirmed by the rupture of the membrane 5-10 min after cell-attached recording. Spontaneous firing rates of $\mathrm{PN}$ neurons were recorded extracellularly in the modified ACSF in a loose-patch configuration (50-250 $\mathrm{M} \Omega$ ) with the pipettes filled with the same ACSF. Signals were acquired using an Molecular Devices MultiClamp 700B amplifier controlled by Clampex 10.2 software via a Digidata 1440A interface (Molecular Devices). Responses were filtered at $2 \mathrm{kHz}$, digitized at $10 \mathrm{kHz}$, and analyzed using Clampfit 10.2 (Molecular Devices) and Mini Analysis 6.0 software (Synaptosoft). The root-mean-square noise level was $2-4 \mathrm{pA}$ and a threshold of 10-12 pA was used to detect and measure mIPSCs, sIPSCs, and mEPSCs. One-hundred to 200 individual events for mIPSCs, sIPSCs, and mEPSCs each were taken from recordings with a Ra ranging 8-12 $\mathrm{M} \Omega$ every $30 \mathrm{~s}$ to $1 \mathrm{~min}$, which is important for detecting miniature events because under this condition, those miniature responses with low amplitude were also included in the recordings; a total of 500-1000 individual events were analyzed for each neuron. All collected events were averaged for the amplitude and kinetics measurements. Recordings in FS basket cells were done with the pipette solution containing $0.2-0.6 \%$ neurobiotin and visualization was completed using a DAB method.

The RMP was the average membrane potential within 2 min after obtaining the whole-cell configuration. Input resistance $\left(R_{\text {in }}\right)$ was calculated from small $(2.5-5 \mathrm{mV})$ voltage deflections induced by rectangular hyperpolarizing current injections $(50 \mathrm{pA})$. The membrane time constant $\left(\tau_{\mathrm{m}}\right)$ was obtained by fitting a single exponential function to these same hyperpolarizing voltage deflections. We used the first spike evoked by the minimum current needed to elicit an $\mathrm{AP}$ applied from $-70 \mathrm{mV}$ to quantify spike properties. AP amplitude was calculated as the voltage difference between AP threshold and AP peak. AP duration was measured as the duration at half-maximal amplitude. AHP amplitude was defined as the voltage difference between AP threshold and the depth of the AHP. Rise time was measured between 20 and $80 \%$ of the peak of the uPSC1; the decay time constant $(\tau)$ was measured by fitting a single exponential to the decay phase of the uPSC1.



Figure 1. Light micrograph of a neurobiotin-stained EGFP-expressing FS basket cell in P60 G42 mice. Arrows indicate the axonal arbors that form "basket" terminals. Scale bar, $50 \mu \mathrm{m}$.
B $\mathrm{PO}$



EGFP





C $\mathrm{P} 60$ Cont $\mathrm{KO} \quad \mathrm{kDa}$



Figure 2. Conditional knock-out of the erbb4 gene in interneurons resulted in an absence of ErbB4 protein in the PFC. $A$, ErbB4 protein was almost completely abolished in PO KO mice. $\boldsymbol{B}$, ErbB4 protein level was below the detection limit in EGFP-positive neurons in P16 K0 G42 mice. Scale bar, $10 \mu \mathrm{m}$. C, Full-length blots of ErbB4 immunoreactivity demonstrate specificity.

Statistical analysis. Fisher's exact test was used to determine changes in the percentage of connected pairs. The Kolmogorov-Smirnov test (K-S test) was used to compare the frequency distributions of mIPSCs, mEPSCs, and sIPSCs. Unless otherwise specified, statistical analyses were performed with one-way ANOVA or independent Student's $t$ test for data that are expressed as mean \pm SEM. Data used for statistical analyses in each group were from at least six mice. $n$ is the number of mice. Generally, 2-5 neurons or pairs were averaged for each mouse. Differences were considered significant if $p<0.05$. Cell pairs with a minimal uIPSC1 or uEPSC1 value of $15 \mathrm{pA}$ were used to assess the short-term plasticity in Figures $4 B, 5 B$, and $7 B$.

\section{Results}

\section{Identification of FS basket interneurons}

To identify FS cells, we took advantage of the G42 mice line, in which previous studies have shown that most, if not all, of the EGFP-expressing neurons are PV interneurons (Chattopadhyaya et al., 2004). We found that most EGFP-positive neurons with multipolar dendritic trees lacking apparent apical and/or basal dendrites and with a round/oval shape and a soma diameter $>10$ $\mu \mathrm{m}$ were FS neurons showing abrupt episodes of nonadapting repetitive discharges (Kawaguchi and Kubota, 1997; 94\%, 320/ 342 neurons from 65 mice). We further confirmed that the expression of EGFP in G42 mice is largely, if not exclusively, restricted to PV FS basket cells in the mPFC (Fig. 1; 42/42 cells carefully examined showed typical basket cell morphology from 20 mice). This is consistent with a recent study from Huang's laboratory showing that most chandelier cells are actually PVnegative in the mPFC (Taniguchi et al., 2013). Thus, EGFP acts as 




B



C



D $\mathrm{P} 60$



E

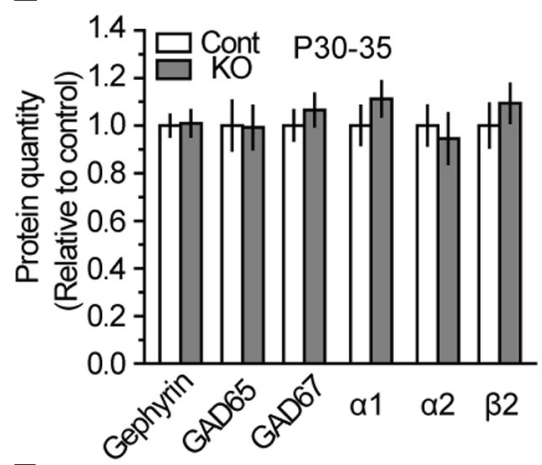

$\mathbf{F}$

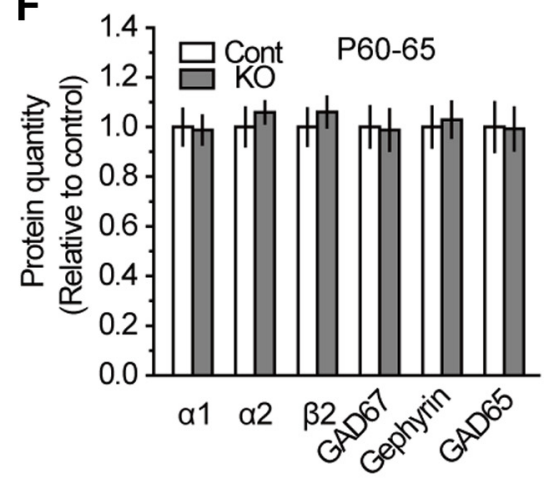

Figure 3. The PFC developed normally in KO mice. A, Coronal brain sections immunostained with NeuN (top), and PV (bottom) in the P30 PFC of control and KO mice. Roman numerals (I, II, III, $\mathrm{V}, \mathrm{VI}$ ) indicate cortical layers. Scale bar, $100 \mu \mathrm{m}$. B, Quantification of the laminar distribution of PV neurons did not differ significantly between control and KO mice. $\boldsymbol{C}$, Western blots of the PFC using antibodies against gephyrin, GAD65, GAD67, $\alpha 1, \alpha 2, \beta 2, \beta$-actin, and GAPDH revealed similar protein expression levels in P30 K0 mice compared with their control littermates. $\boldsymbol{D}$, The same as for $\boldsymbol{C}$ in P60 mice. $\boldsymbol{E}$, Relative protein quantification of gephyrin, GAD65, GAD67, $\alpha 1, \alpha 2$, and $\beta 2$ showed no significant difference between control and K0 mice. All values were normalized to control, and the data in control were given a value of 1. $\boldsymbol{F}$, The same as for $\boldsymbol{E}$ in P60 mice. Mean \pm SEM.

a reliable marker for a subset of PV FS basket cells in the mPFC in G42 mice.

\section{GABAergic synapses developed normally in the mPFC} without erbb4

We genetically deleted ErbB4 receptors by crossing erbb $4^{f l f l}$ mice with Dlx5/6-Cre mice that begin to express Cre recombinase in GABAergic forebrain neurons at embryonic day 10 (Shimamura et al., 1997; Zerucha et al., 2000). Mutant mice (Dlx5/6erbb4 ${ }^{-1-}$ ) were viable and will be referred to as $\mathrm{KO}$ mice. Littermates carrying either the CRE gene (Dlx5/6-Cre;erbb $4^{+/+}$) or floxed $\left(e r b b 4^{f / f}\right)$ alleles were not distinguishable from wild-type mice in terms of newborn survival rate, general health, such as fur color, appetite, and body weight (data not shown) and were used as controls. The deletion of ErbB4 at postnatal day (P) 0 was confirmed by immunoblots (Fig. $2 \mathrm{~A}$ ); this is a time when cortical networks are poorly developed. Conditional knock-out of the erbb4 gene from interneurons resulted in a near-complete absence of ErbB4 protein in the PFC by Western and immunohistochemical analysis (Fig. 2). The specificity of ErbB4 antibody was established on cortical sections from $\mathrm{KO}$ mice (Fig. $2 B$ ), and the antibody reacted with one single band of $\sim 180 \mathrm{kDa}$ on the Western blots (Fig. 2C). Thus, these data suggest that at least in the PFC, PN neurons express very few, if any, ErbB4 receptors.
This supports the notion that ErbB4 is preferentially expressed by interneurons, but is absent from PNs (Vullhorst et al., 2009; Fazzari et al., 2010). In agreement with previous studies from ErbB2/4 double-mutant mice (Barros et al., 2009; Gajendran et al., 2009), we found that KO mice showed normal development of cortical layers, and the laminar distribution of both NeuNpositive neurons and PV interneurons was similar (Fig. 3A). Further detailed quantification of the laminar distribution of PV interneurons (Fig. 3B) indicated no significant difference between the genotypes. The PV neuron soma size [P30-P35; control (Cont), $245.40 \pm 10.54 \mu \mathrm{m}^{2}, n=12(47$ cells $) ; \mathrm{KO}, 238.42 \pm$ $9.34 \mu \mathrm{m}^{2}, n=11$ (55 cells), $t$ test, $\left.p>0.05\right]$ and the number of primary dendrites of FS basket cells [P16-P20; Cont, $6.38 \pm 0.45$, $n=7$ ( 13 cells); KO, $5.93 \pm 0.61, n=7$ ( 14 cells), $t$ test, $p>0.05$ ] between controls and $\mathrm{KO}$ was similar. We then assessed the protein expression levels of GAD65, GAD67, and gephyrin, markers of GABAergic synapses, at P30-P35 and P60-P65 (Fig. 3 C,D). We found very similar levels of GAD65, GAD67, and gephyrin (Fig. $3 E, F)$. We also assessed the protein expression of the $\alpha 1$, $\alpha 2$, and $\beta 2 \mathrm{GABA}_{\mathrm{A}}$ receptor subunits (Fig. $3 C, D$ ), again, no difference was found between $\mathrm{KO}$ and control mice (Fig. $3 E, F$ ).

$\mathrm{PNs}$ are the major target for FS interneurons in the neocortex. The expression of ErbB4 on the axon terminals of FS neurons (Yau et al., 2003; Woo et al., 2007; Fazzari et al., 2010) prompted 


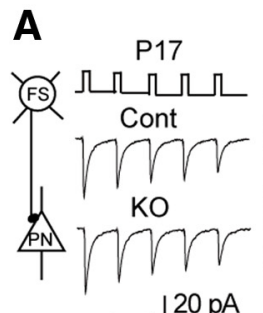

$50 \mathrm{~ms}$



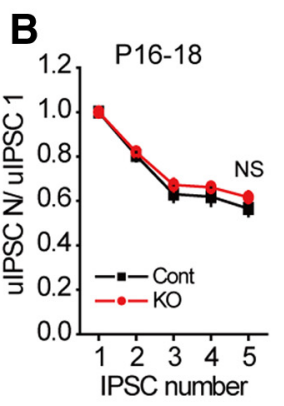

E

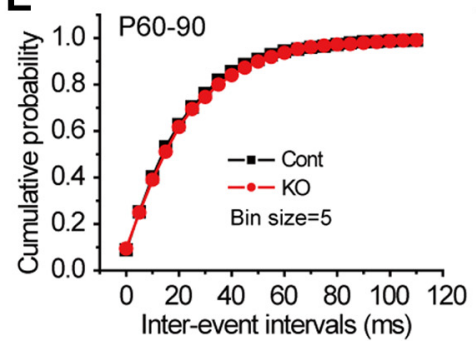

C



F



Figure 4. GABAergic synapses on PNs formed by FS basket cells developed lacking ErbB4. A, uIPSCs were induced in PNs by eliciting action potentials in FS neurons from a control (upper) and a KO (lower) P17 mouse. Traces are the average of 50 trials. $\boldsymbol{B}$, Short-term plasticity was not changed. Mean \pm SEM. NS, not significant. $\boldsymbol{C}$, vGAT- and PV-labeled presynaptic terminals around PN somata immunostained with NeuN antibody in P30 and P60 mice. Each image is a single confocal plane. Scale bars, $5 \mu \mathrm{m}$ (P30); $10 \mu \mathrm{m}$ (P60). D, Representative traces of mIPSCs from P60 PN neurons. $(\boldsymbol{E}, \boldsymbol{F})$ Cumulative plots of mIPSC frequencies $(\boldsymbol{E})$ and amplitudes $(\boldsymbol{F})$.

us to investigate whether GABAergic synaptogenesis between FS basket cells and PN neurons is dependent on ErbB4. To detect synaptic connections specifically formed by locally projecting FS basket cells, we crossed KO mice with G42 mice (hereafter referred to as G42 KO mice), and performed simultaneous wholecell recordings from pairs of FS cells and PN neurons $(<20 \mu \mathrm{m}$ apart) in mPFC layers V/VI from mice aged P16-P18 (Fig. 4A). We found no significant difference in either the connection probability (Cont, 45 of 122 pairs were connected; KO, 60/136; Fisher's exact test, $p>0.05)$ or the average amplitude of the first uIPSCs in the train (uIPSC1; Cont, $50.38 \pm 11.22 \mathrm{pA}, n=26$; $\mathrm{KO}, 56.85 \pm 13.98 \mathrm{pA}, n=30$; $t$ test, $p>0.05)$, suggesting that the total synapse number is not affected by ErbB4 deletion. The kinetics of uIPSC1 was similar (rise time: Cont, $0.49 \pm 0.02, \mathrm{KO}$, $0.50 \pm 0.02$; $t$ test, $p>0.05$; decay $\tau$ : Cont, $6.51 \pm 0.27, \mathrm{KO}$, $6.62 \pm 0.31 ; t$ test, $p>0.05)$. Short-term depression of uIPSCs in $\mathrm{G} 42 \mathrm{KO}$ mice was indistinguishable from that in controls (Fig. $4 B)$. We then counted the number of GABAergic boutons around PN neuron somata by double-immunostaining cortical sections for the inhibitory presynaptic marker vGAT or PV, and for NeuN in P30-P35 and P60-P65 mice (Fig. 4C). Knock-out of ErbB4 had little effect on the bouton density [boutons/soma area $\left(/ \mu \mathrm{m}^{2}\right), \mathrm{P} 30-\mathrm{P} 35, \mathrm{vGAT}$, Cont, $0.051 \pm 0.004, n=8$ (21 cells); $\mathrm{KO}, 0.052 \pm 0.004, n=10$ (26 cells), $t$ test, $p>0.05$; P60-P65, vGAT, Cont, $0.066 \pm 0.005, n=11$ (29 cells); KO, $0.058 \pm 0.005$, $n=10$ ( 25 cells), $t$ test, $p>0.05$; PV, Cont, $0.081 \pm 0.004, n=15$ ( 34 cells); KO, $0.082 \pm 0.003, n=16$ (38 cells), $t$ test, $p>0.05$ ]. To further confirm our observations, we then recorded mIPSCs from mPFC layers V/VI PN neurons in P60-P90 mice at nearphysiological temperature $\left(34 \pm 2{ }^{\circ} \mathrm{C}\right.$; Fig. $\left.4 D\right)$. PV FS basket interneurons preferentially synapse on the somata and proximal dendrites of their targets (Williams et al., 1992), and most mIPSCs originate from proximally located synapses (Soltesz et al., 1995), which thus may reflect their FS interneuronal origin. Analysis of the mIPSC frequency [Fig. 4E; Cont, $38.98 \pm$ $3.43 \mathrm{~Hz}, n=12$ (25 cells); KO, $40.24 \pm 2.68 \mathrm{~Hz}, n=14$ (24 cells), K-S test, $p>0.05$ ] and amplitude (Fig. 4F; Cont,
$40.98 \pm 1.98 \mathrm{pA} ; \mathrm{KO}, 40.44 \pm 2.38 \mathrm{pA}, t$ test, $p>0.05)$ revealed no difference, suggesting no change in the number of release sites and/or release probability.

PV FS interneurons are extensively interconnected via chemical synapses. In addition to axon terminals, ErbB4 is also abundantly expressed on the somatodendritic regions of FS neurons (Yau et al., 2003; Woo et al., 2007; Vullhorst et al., 2009; Fazzari et al., 2010). To investigate whether ErbB4 signaling is required for GABAergic synaptogenesis among FS basket cells, we first performed simultaneous whole-cell recordings from pairs of FS neurons $(<100 \mu \mathrm{m}$ apart) in layers V/VI of the mPFC in mice aged P16-P18 (Fig. 5A). Neither the connection probability (Cont, 33 of 52 pairs were connected; KO, 41/62; the Fisher's exact test, $p>$ 0.05; reciprocal IPSCs, Cont, 20/52; KO, 27/62; Fisher's exact test, $p>0.05)$ nor the average amplitude of uIPSC1 [Cont, $59.23 \pm$ $9.87 \mathrm{pA}, n=12$ (32 cells); KO, $65.35 \pm 13.33 \mathrm{pA}, n=13$ (33 cells), $t$ test, $p>0.05$ ] among FS interneurons was distinguishable between control and KO mice. The kinetics of UIPSC1 was not altered (rise time: Cont, $0.51 \pm 0.02 ; \mathrm{KO}, 0.50 \pm 0.02$, $t$ test, $p>0.05$; decay $\tau$ : Cont, $3.86 \pm 0.17 ; \mathrm{KO}, 3.91 \pm 0.18, t$ test, $p>$ $0.05)$. Short-term depression of uIPSCs from G42 KO mice was comparable to that of controls (Fig. 5B). Double-staining with $\mathrm{PV}$ and vGAT showed identical results for P30-P35 and P60-P65 control and $\mathrm{KO}$ mice [Fig. $5 \mathrm{C}$; boutons/soma area $\left(/ \mu \mathrm{m}^{2}\right), \mathrm{P} 30-$ P35, Cont, $0.043 \pm 0.004, n=8$ (21 cells); KO, $0.046 \pm 0.008, n=$ 9 (26 cells), $t$ test, $p>0.05$; P60-P65, Cont, $0.051 \pm 0.004, n=10$ ( 28 cells); KO, $0.044 \pm 0.049, n=9$ ( 24 cells), $t$ test, $p>0.05]$. We then recorded mIPSCs from $\mathrm{mPFC}$ layers V/VI FS interneurons in $\mathrm{P} 60-\mathrm{P} 90$ mice at $34 \pm 2{ }^{\circ} \mathrm{C}$ (Fig. $5 D$ ). Neither the frequency [Fig. 5E; Cont, $95.46 \pm 8.33 \mathrm{~Hz}, n=12$ (21 cells); KO, $97.46 \pm$ $7.39 \mathrm{~Hz}, n=14$ (25 cells), K-S test, $p>0.05$ ] nor the amplitude (Fig. 5F; Cont, $60.45 \pm 3.95$ pA; KO, $62.35 \pm 3.92$ pA, $t$ test, $p>$ $0.05)$ of mIPSCs was altered by the deletion of ErbB4.

Thus, these findings suggest that ErbB4 is dispensable for the development of GABAergic synapses by FS basket cells in the PFC in vivo. Compensation for the lack of ErbB4 by other ErbB family members such as ErbB2 is unlikely because examination of the 
A

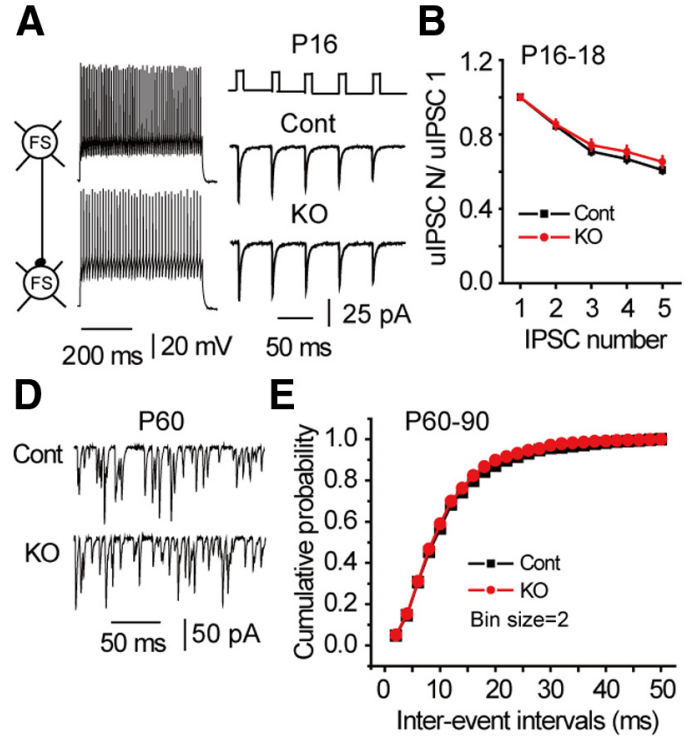

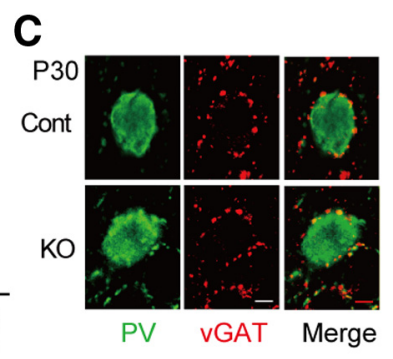

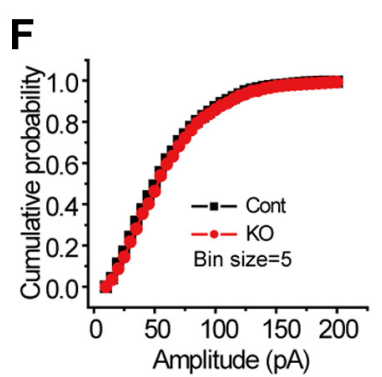

Figure 5. ErbB4 signaling was not required for the development of chemical connections among FS basket cells. $A$, ulPSCS were induced in postsynaptic neurons by eliciting APs in the chemically coupled presynaptic neurons via injection of depolarizing currents from a control (top) and a KO (bottom) FS-FS pair in P16 mice. Traces are the average of 50 trials. Left, Insets, The firing patterns of both postsynaptic FS interneurons. Recordings were done in the presence of mefloquine ( $50 \mu \mathrm{m}$; to block gap junctions). $\boldsymbol{B}$, Short-term plasticity was unaltered in KO mice. Mean \pm SEM. NS, Not significant. C, vGAT-labeled presynaptic terminals around PV neuron somata in P30 mice. Each image is a single confocal plane. Scale bar, $5 \mu \mathrm{m}$. $\boldsymbol{D}$, Representative traces of mIPSCS recorded from FS basket cells in P60 mice. $\boldsymbol{E}, \boldsymbol{F}$, Cumulative plots of mIPSC frequencies $(\boldsymbol{E})$ and amplitudes $(\boldsymbol{F})$.

$0.44 \pm 0.01 ; \mathrm{KO}, 0.44 \pm 0.01 ; t$ test, $p>$ 0.05 ; decay $\tau$ : Cont, $2.29 \pm 0.47 ; \mathrm{KO}$, $2.32 \pm 0.52 ; t$ test, $p>0.05)$. Short-term depression of uEPSCs from G42 KO mice was similar to that of controls (Fig. $7 B$ ). We then double-stained cortical sections for the excitatory presynaptic marker vGluT1 and for PV in P14-P16 mice (Fig. $7 C)$; detailed quantification showed that deletion of ErbB4 had no effect on vGluT1 bouton density around PV soma in P14P16 KO mice [boutons/soma area $\left(/ \mu \mathrm{m}^{2}\right)$, Cont, $0.055 \pm 0.003, n=8(24$ cells); KO, $0.054 \pm 0.003, n=9$ (25 cells), $t$ test, $p>0.05]$. When mEPSCs were recorded from mPFC layers V/VI FS basket cells in P18-P20 mice at $34 \pm 2^{\circ} \mathrm{C}$ (Fig. $7 D$ ), neither the frequency [Fig. $7 E$; Cont, $24.54 \pm 3.83 \mathrm{~Hz}, n=10$ (21 cells); KO, $25.63 \pm 2.84 \mathrm{~Hz}, n=11$ (25 cells), K-S test, $p>0.05$ ] nor the amplitude (Fig. $7 F$; Cont, $22.00 \pm 1.31 \mathrm{pA}$; KO, $21.47 \pm 1.06$ $\mathrm{pA}, t$ test, $p>0.05)$ of mEPSCs was altered in G42 KO mice compared with controls. Thus, these data suggest that ErbB4 is dispensable for early development of glutamatergic synapses on FS basket cells.

However, at P40-P45, knock-out of

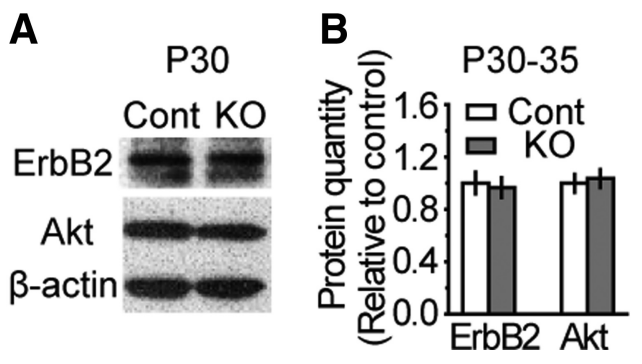

Figure 6. The lack of ErbB4 was not compensated for by ErbB2. $A$, Expression levels of ErbB2 and Akt protein in $\mathrm{P3} 0$ control and $\mathrm{KO}$ mice were similar. $\boldsymbol{B}$, There was no significant difference in the protein expression levels of ErbB2 and Akt in both genotypes. Mean $\pm S E M ; n=6$ mice per genotype.

protein expression levels of ErbB2, together with Akt, which is a major downstream effector of the ErbB signaling pathway (Mei and Xiong, 2008), revealed no significant difference between genotypes (Fig. 6).

\section{ErbB4 signals controlled glutamatergic synaptogenesis on FS basket cells}

FS interneurons receive abundant excitatory inputs from PN neurons. The colocalization of ErbB4 with PSD-95 (Garcia et al., 2000; Huang et al., 2000) prompted us to determine whether ErbB4 signaling is essential for glutamatergic synaptogenesis on FS basket cells. We first performed simultaneous whole-cell recordings from pairs of PNs and FS cells ( $<20 \mu \mathrm{m}$ apart) in layers V/VI of the mPFC in mice aged P16-P18 (Fig. 7A). We found that both the connection probability (Cont, 25/122 pairs were connected; KO, 31/136; Fisher's exact test, $p>0.05)$ and the average amplitude of the first unitary EPSCs (uEPSC1; Cont, $44.99 \pm 11.93 \mathrm{pA}, n=22 ; \mathrm{KO}, 56.43 \pm 10.92 \mathrm{pA}, n=28, t$ test, $p>0.05)$ between PNs and FS basket cells were comparable between control and G42 KO mice. The kinetics of uEPSC1 of both groups were statistically indistinguishable (rise time: Cont,
ErbB4 resulted in a significant decrease in vGluT1 bouton density on PV somata [Fig. $8 A$; boutons/soma area $\left(/ \mu \mathrm{m}^{2}\right)$, Cont, $0.122 \pm 0.004, n=8$ (19 cells); KO, $0.081 \pm 0.004, n=8(24$ cells), $t$ test, $p<0.001$ ]. We then recorded mEPSCs from mPFC layers V/VI FS neurons in P60-P90 mice at $34 \pm 2^{\circ} \mathrm{C}$ (Fig. $8 B$ ). Although the frequency of mEPSCs was significantly reduced in KO mice [Fig. 8C; Cont, $95.32 \pm 7.32 \mathrm{~Hz}, n=12$ (31 cells); $\mathrm{KO}$, $76.17 \pm 5.65 \mathrm{~Hz}, n=10$ (26 cells), K-S test, $p<0.05]$, the amplitude of mEPSCs was largely unaltered (Fig. $8 D$; Cont, $28.86 \pm 0.90 \mathrm{pA} ; \mathrm{KO}, 26.92 \pm 1.22 \mathrm{pA}, t$ test, $p>0.05)$. Most NMDA receptors were closed at $-70 \mathrm{mV}$ with normal concentrations of $\mathrm{Mg}^{2+}$; hence, the unaltered mEPSC amplitude might suggest no apparent change in AMPA-R component of synaptic transmission. We then recorded eEPSC $_{\mathrm{NMDAR}}$ at $+50 \mathrm{mV}$ with the stimulus strength carefully adjusted to evoke $\sim 200 \mathrm{pA}$ of eEPSC $_{\text {AMPAR }}$ which was induced from all recorded FS neurons at $-70 \mathrm{mV}$. We found that both the probability of finding a FS neuron expressing NMDAR currents and the NMDA/AMPA ratio showed a trend of decrease in $\mathrm{KO}$ mice (Fig. $8 E$; coupling probability: Cont, 30 of 42 FS neurons from 10 mice expressed eEPSC $_{\text {NMDAR }}$ KO, 19/44 FS neurons, 11 mice, Fisher's exact test, $p>0.05$; NMDA/AMPA ratio: Cont, $0.25 \pm 0.14$; KO, $0.11 \pm$ $0.08, t$ test, $p>0.05)$. Together, these data suggest that ErbB4 signals regulate the maturation of glutamatergic synapses on FS basket cells.

\section{Activity-dependent GABAergic FS-PN transmission was reduced without $e r b b 4$}

So far, our data show that in the mouse PFC in vivo, ErbB4 signaling regulates glutamatergic synaptogenesis, but not GABAergic synaptogenesis. However, several previous studies demonstrate that ErbB4 is involved in acute regulation of activity-dependent GABAergic FS-PN transmission (Woo et al., 2007; Chen et al., 2010; Li et al., 2012 b). To determine whether this is also the case during development, we then recorded AP-dependent sIPSCs on PNs (Fig. 9A). In 
contrast to AP-independent mIPSCs on PN cells (Fig. $4 D-F$ ), when TTX was absent from the bath solution, the frequency of sIPSCs was significantly reduced in $\mathrm{KO}$ mice (Fig. 9B). Although the amplitude of sIPSCs showed a slight decrease, the difference was not statistically significant (Fig. 9B). These data suggest that a deletion of ErbB4 in FS interneurons results in a reduction of activity-dependent GABAergic FS-PN transmission. Next, we further investigated whether the activity of FS neurons was altered in P60-P90 KO mice. First, we injected depolarizing current to induce AP firing in FS neurons. The Rheo-base current (RI) was determined as the minimum current needed to elicit an AP applied from a holding potential $\left(\mathrm{V}_{\mathrm{h}}\right)$ of $-70 \mathrm{mV}$ via a series of $10 \mathrm{~ms}$ step current injections with increments of $10 \mathrm{pA}$. Compared with control littermates, RI was significantly increased in KO mice [Cont, $383.84 \pm 25.49 \mathrm{pA}, n=12$ ( 19 cells); KO, $520.64 \pm 29.86$ pA, $n=13$ (21 cells), $t$ test, $p<0.05$ ]. We also examined the relationship between somatic current injection and AP firing in FS neurons from $\mathrm{KO}$ and control animals. FS basket cells were stimulated with a series of $500 \mathrm{~ms}$ step depolarizing current pulses $\left(\mathrm{V}_{\mathrm{h}},-70 \mathrm{mV}\right.$; increment, $50 \mathrm{pA}$ ). We found that in FS neurons from $\mathrm{KO}$ mice, the number of APs was significantly lower than in control littermates at 600 and 650 pA depolarizing levels (Fig. 9 C,D). We further assessed the activity of PV neurons by recording the spontaneous firing rate and found that FS neuron activity was significantly decreased in $\mathrm{KO}$ mice (Fig. 9E; Cont, $2.54 \pm 0.45 \mathrm{~Hz}, n=10$; $\mathrm{KO}, 0.52 \pm 0.41 \mathrm{~Hz}, n=10$, $t$ test, $p<0.05$ ). Meanwhile we assessed the passive and active membrane properties of FS neurons in P60-P90 mice (Table 1). Although most of the intrinsic membrane properties were largely unaltered, membrane input resistance $\left(R_{\text {in }}\right)$ was significantly reduced in $\mathrm{KO}$ mice (Table 1). An increase in the linear leak current by $17.13 \%$ in $\mathrm{KO}$ mice compared with controls may partially account for the decrease of $R_{\text {in }}$. Although it is currently unknown what causes the increase in the leak current in FS neurons in the KO mouse, we found no difference in the amplitude of $R_{\text {in }}$ with $\mathrm{Cs}^{+}$substituted for $\mathrm{K}^{+}$and TEA present in the pipette solution to block potassium channels [these solutions were used to record mIPSCs and mEPSCs; Cont, $96.25 \pm 6.26$ $\mathrm{M} \Omega, n=24$ ( 52 cells); KO, $93.34 \pm 5.85 \mathrm{M} \Omega, n=24$ (51 cells), $t$ test, $p>0.05$ ], suggesting an activation of potassium channels at the RMP in KO mice. To find out whether deletion of ErbB4 causes any defect in the membrane properties and the spontaneous firing rate of FS neurons at P16-P20, additional experiments were done and no difference was found $\left(R_{\text {in }}\right.$ : Cont, $132.23 \pm 12.39$ $\mathrm{M} \Omega, n=15$ cells $/ 6$ mice; KO, $125.65 \pm 10.11 \mathrm{M} \Omega, n=16$ cells/ 7 mice; $t$ test, $p>0.05$; spontaneous firing rate: Cont,
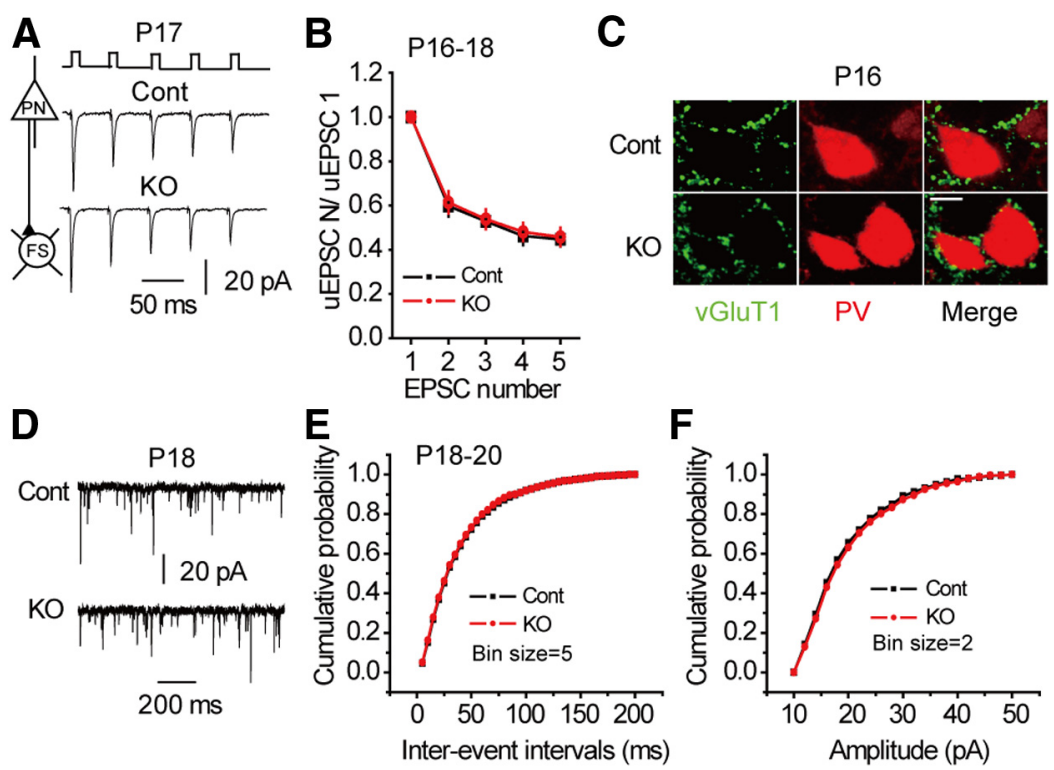

Figure 7. The initial formation of glutamatergic synapses on FS basket cells was not affected by ErbB4 signaling. $\boldsymbol{A}$, uEPSCs were induced in postsynaptic FS neurons by eliciting APs in presynaptic PNs from a control (top) and a KO (bottom) PN-FS pair in P17 mice. Traces are the average of 50 trials. $\boldsymbol{B}$, Short-term plasticity was not changed in KO mice; mean \pm SEM. $\boldsymbol{C}$, vGluT1-labeled presynaptic terminals on PV neuron somata in P16 mice. Each image is a single confocal plane. Scale bar, $10 \mu \mathrm{m}$. $\boldsymbol{D}$, Representative traces of mEPSCs recorded from FS basket cells in P18 mice. $\boldsymbol{E}, \boldsymbol{F}$, Cumulative plots of mEPSC frequencies $(\boldsymbol{E})$ and amplitudes $(\boldsymbol{F})$.
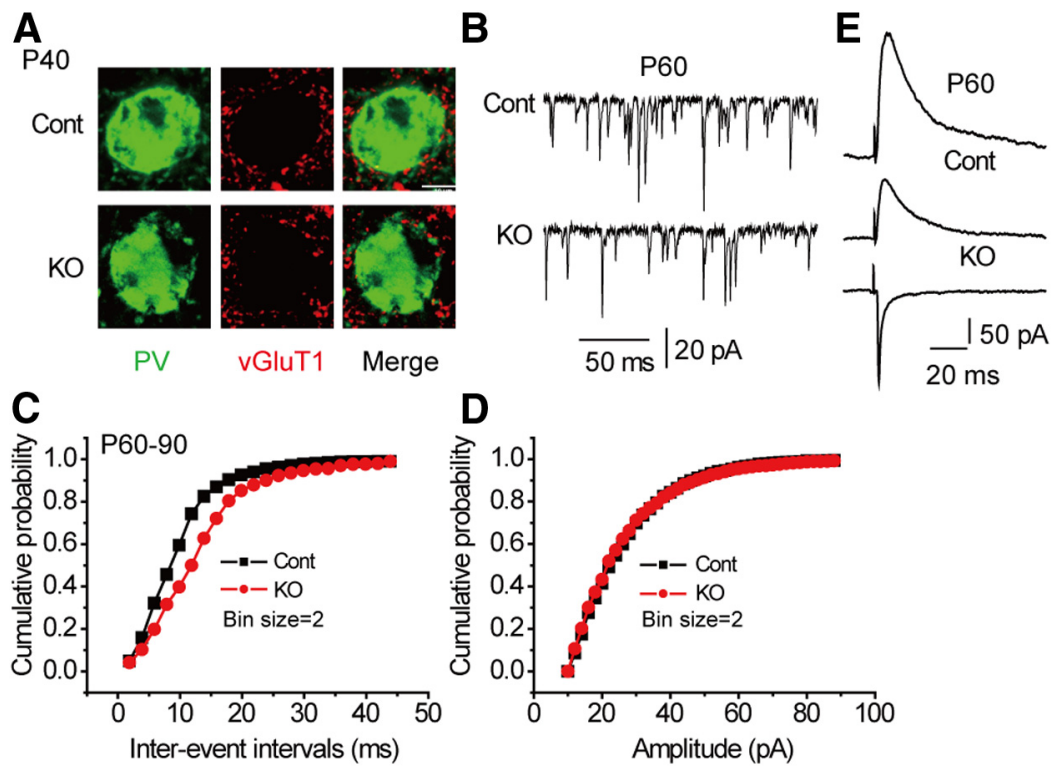

Figure 8. The maturation of glutamatergic synapses on FS basket cells was disrupted in the absence of ErbB4 signaling. $\boldsymbol{A}$, vGluT1-labeled presynaptic terminals around PV neuron somata in P40 mice. Each image is a single confocal plane. Scale bar, $10 \mu \mathrm{m} . B$, Representative traces of $\mathrm{mEPSC}$ recorded from FS neurons in P60 mice. $\boldsymbol{C}$, $\boldsymbol{D}$, Cumulative plots of mEPSC frequencies $(\boldsymbol{C})$ and amplitudes $(\boldsymbol{D})$. $\mathrm{mEPSC}$ frequencies were significantly reduced in $\mathrm{KO}$ mice. $E$, There is a trend of decrease in the amplitude of eEPSC $\mathrm{NMDAR}_{\mathrm{N}}$ in $\mathrm{KO}$ mice.

$1.05 \pm 0.55 \mathrm{~Hz}, n=12$ cells $/ 6$ mice; $\mathrm{KO}, 0.96 \pm 0.45 \mathrm{~Hz}, n=$ 14 cells $/ 6$ mice, $t$ test, $p>0.05)$. Together, these data suggest that a deletion of ErbB4 in FS basket cells results in a decrease in the activity of these cells, which may in turn reduce activitydependent GABAergic FS-PN transmission.

\section{PN neuronal activity was increased in $\mathrm{KO}$ mice}

We went on to determine whether the activity of PN neurons was altered in KO mice. As shown in Table 1, neither the passive nor the active membrane properties of $\mathrm{PN}$ neurons in layer V/VI was altered with the deletion of ErbB4. However, when spontaneous 
A

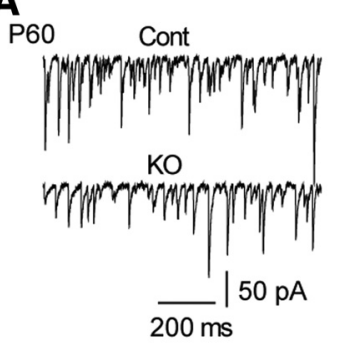

B

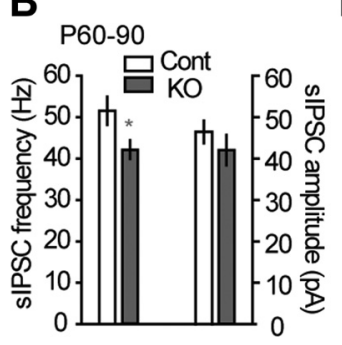

D

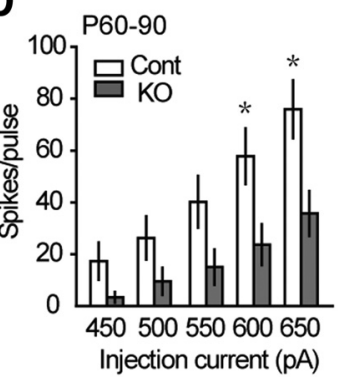

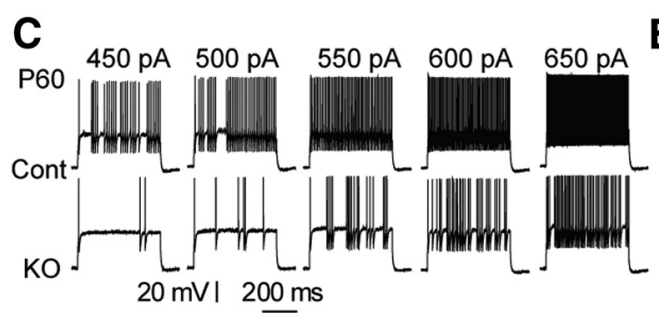

$\mathbf{E}_{\mathrm{P} 60}$

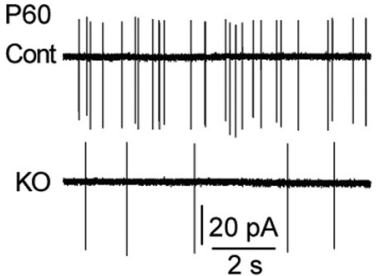

Figure 9. Activity-dependent GABAergic FS-PN transmission was reduced in $\mathrm{KO}$ mice. $\boldsymbol{A}$, Representative traces of sIPSCs recorded from PNs in P60mice. $\boldsymbol{B}$, SIPSC frequency butnot amplitude was significantly decreased in KO mice. C, Representativetraces of APfiring elicited in response to 500 ms suprathreshold current of $450-650 \mathrm{pA}$ recorded from $\mathrm{FS}$ basket cells in $\mathrm{P} 60$ mice; $\mathrm{V}_{\mathrm{h}^{\prime}}-70 \mathrm{mV}$; increment, $50 \mathrm{pA}$. D, Plots of firing frequency (spikes/pulse) revealed significant differences between Cont and $K 0$ mice at $600 \mathrm{pA}$ and $650 \mathrm{pA}$ depolarizing levels. $\boldsymbol{E}$, Representative traces of spontaneous firing rate of FS neurons in P60 mice; mean \pm SEM in $B, D ;{ }^{*} p<0.05$.

Table 1. Intrinsic properties of FS basket cells and PNs in control and KO adult (P60-P90) mice

\begin{tabular}{|c|c|c|c|c|}
\hline & \multicolumn{2}{|l|}{ FS basket cells } & \multicolumn{2}{|l|}{ PNs } \\
\hline & Control $(n=8)$ & $\mathrm{KO}(n=8)$ & Control $(n=8)$ & $\mathrm{KO}(n=8)$ \\
\hline$C_{m}(p F)$ & $56.35 \pm 2.83$ & $59.66 \pm 3.23$ & $178.42 \pm 8.38$ & $186.99 \pm 9.34$ \\
\hline $\operatorname{RMP}(\mathrm{mV})$ & $-64.44 \pm 1.67$ & $-64.89 \pm 0.94$ & $-68.71 \pm 0.71$ & $-69.06 \pm 0.68$ \\
\hline$\tau_{\mathrm{m}}(\mathrm{ms})$ & $4.16 \pm 0.16$ & $3.91 \pm 0.25$ & $13.63 \pm 0.66$ & $14.53 \pm 1.06$ \\
\hline$R_{\text {in }}(\mathrm{M} \Omega)$ & $82.67 \pm 4.69$ & $63.68 \pm 3.82^{*}$ & $78.42 \pm 4.12$ & $80.75 \pm 4.48$ \\
\hline AP threshold (mV) & $-40.63 \pm 0.52$ & $-40.32 \pm 0.43$ & $-43.16 \pm 0.57$ & $-43.88 \pm 0.81$ \\
\hline AP amplitude (mV) & $59.73 \pm 2.35$ & $57.35 \pm 1.58$ & $85.45 \pm 1.69$ & $86.21 \pm 1.60$ \\
\hline AP duration (ms) & $0.23 \pm 0.01$ & $0.23 \pm 0.01$ & $0.62 \pm 0.01$ & $0.63 \pm 0.01$ \\
\hline AHP amplitude (mV) & $19.25 \pm 0.95$ & $18.68 \pm 0.73$ & $9.45 \pm 0.56$ & $10.07 \pm 0.48$ \\
\hline Soma size $\left(\mu \mathrm{m}^{2}\right)$ & $269.34 \pm 13.41$ & $279.35 \pm 13.25$ & $\mathrm{~N} / \mathrm{A}$ & $N / A$ \\
\hline $\operatorname{RI}(p A)$ & $383.84 \pm 25.49$ & $520.64 \pm 29.86$ & $282.14 \pm 15.32$ & $292.50 \pm 19.21$ \\
\hline
\end{tabular}

Mean \pm SEM; ${ }^{*} p<0.05$ compared with control. $C_{m}$, Membrane capacitance; RMP, resting membrane potential; $\tau_{\mathrm{m}}$, membrane time constant; $R_{\mathrm{in}}$, membrane input resistance; AP, action potential; AHP, afterhyperpolarization; $\mathrm{RI}$, Rheo-base current; N/A, no answer.

firing rate was detected in $\mathrm{PN}$ neurons, a significant increase was observed in $\mathrm{KO}$ mice (Cont, $35.40 \pm 3.86 \mathrm{~Hz}, n=14$ cells $/ 8$ mice; $\mathrm{KO}, 52.55 \pm 3.78 \mathrm{~Hz}, n=15$ cells/10 mice, $t$ test, $p<0.05)$, consistent with a recent study showing that ErbB4 signals are involved in the regulation of PN neuronal activity (Wen et al., 2010). An increase in PN neuronal activity and a decrease in activity-dependent inhibitory inputs onto PNs would lead to an increase in excitatory inputs onto FS neurons. Contrary to our expectations; however, when sEPSCs were recorded on PV FS neurons, we found that the frequency of sEPSCs was still reduced in $\mathrm{KO}$ mice (Cont, $99.42 \pm 8.46 \mathrm{~Hz}, n=15$ cells $/ 8$ mice; $\mathrm{KO}$, $82.47 \pm 6.85 \mathrm{~Hz}, n=16$ cells $/ 10$ mice, $\mathrm{K}-\mathrm{S}$ test, $p<0.05)$. Because sEPSCs include AP-dependent EPSCs, which reflects pyramidal cell activity, and AP-independent mEPSCs, which is determined by the number of release sites and/or the release probability of each release site, and because the frequency of mEPSCs on FS neurons were reduced in KO mice, sEPSCs on FS neurons might not properly reflect the pyramidal cell activity. Hence, we recorded sEPSCs on PNs and found that indeed, both the frequency and amplitude of sEPSCs on PNs were increased in KO mice (sEPSC frequency: Cont, $9.02 \pm 1.42 \mathrm{~Hz}, n=16$ cells $/ 8$

mice; $\mathrm{KO}, 15.87 \pm 1.78 \mathrm{~Hz}, n=16$ cells $/ 8$ mice, $\mathrm{K}-\mathrm{S}$ test, $p<0.05$; sEPSC amplitude: Cont, $20.85 \pm 1.96 \mathrm{pA} ; \mathrm{KO}, 28.07 \pm$ $2.14 \mathrm{pA}, t$ test, $p<0.05$ ), suggesting an increase in the activity of PNs.

\section{Discussion}

The main findings of this study are as follows. First, GABAergic synapses by FS basket cells developed normally in the $\mathrm{mPFC}$ in erbb4-mutant mice. Second, erbb4 was not required for initial glutamatergic synapse formation on FS basket cells. Third, erbb4 was essential for glutamatergic synapse maturation on FS basket cells. Fourth, activity-dependent GABAergic FS-PN transmission was reduced in erbb4-mutant mice. Fifth, PN neuronal activity was enhanced in erbb4-mutant mice.

Some previous studies suggest that ErbB4 signaling is essential for neural migration and cortical development (Rio et al., 1997; Flames et al., 2004), and loss of ErbB4 signaling alters the tangential migration of cortical interneurons and reduces the number of GABAergic interneurons in the parietal cortex (Flames et al., 2004) and of PV interneurons in the hippocampus (Fisahn et al., 2009; Neddens and Buonanno, 2010). However, we showed here that in the mouse PFC, both the development of cortical layers and the laminar distribution of $\mathrm{NeuN}$ - and PV-positive neurons were largely unaltered in KO mice (Fig. 3). Recent studies showed both normal cortical development and radial glia-mediated neuronal migration in ErbB2/4 double mutant mice (Barros et al., 2009; Gajendran et al., 2009), in which all ErbB signals were inactivated during the embryonic period. These findings in part support our observations. Interestingly, a recent study showed that migrating ErbB4-containing, medial ganglionic eminencederived GABAergic interneurons are repelled by neuregulins, a family of trophic factors for ErbB4 receptors (Li et al., 2012a). The reason underlying the discrepancy is currently unknown. Different mouse models (e.g., erbb4 null knock-out mice; Flames et al., 2004; Fisahn et al., 2009; Neddens and Buonanno, 2010; Li et al., 2012a; vs Dlx5/6-Cre; erbb4 $4^{f l f l}$ mice in this study) and brain regions (e.g., the parietal cortex; Flames et al., 2004) and hippocampus (Fisahn et al., 2009; Neddens and Buonanno, 2010; vs $\mathrm{mPFC}$ in this study) may partly account for the difference. This suggests that ErbB signals may function in context-dependent manners (e.g., brain regions, developmental stages, and cell subtypes).

Recently, Fazzari et al. (2010) reported that ErbB4 is required for GABAergic synaptogenesis mediated by FS chandelier neurons in the hippocampus. Here, we extend these findings by showing that ErbB4 signals play a differential role during GABA circuitry development among FS basket cells in deep layers of the mPFC, where chandelier cells are not particularly abundant (Taniguchi et al., 2013). We found that both the initial formation and maturation of GABAergic synapses on PN neurons and on FS basket cells were largely unaffected by ErbB4 signaling in the PFC (Figs. 4, 5). In accord with our observations, ErbB4 overexpression in dissociated neuronal cultures from hippocampi showed that ErbB4 signaling has no effect on the density, i.e., number per unit length, of vGAT-positive puncta, suggesting that ErbB4 sig- 
naling is not required for initial inhibitory synapse formation (Krivosheya et al., 2008); COS7 cells expressing ErbB4 are not sufficient to promote the formation of inhibitory presynaptic boutons (Krivosheya et al., 2008). Moreover, deletion of ErbB4 in PV interneurons has no effect on basal GABAergic transmission in hippocampal PN neurons (Chen et al., 2010). ErbB4 signals from the periphery also have no effect on the mIPSC frequency and amplitude in layer $\mathrm{V}$ PN neurons from mouse frontal cortex (Abe et al., 2011). These observations, in part, support our findings that ErbB4 signaling is not required for GABAergic synaptogenesis mediated by FS basket cells. The lack of actions of ErbB4 signals on GABAergic synaptogenesis is possibly due to very rare, if any, ErbB4 expression on GABAergic terminals (Vullhorst et al., 2009; Neddens et al., 2011). Alternatively, this may suggest that ErbB4 signals may function differentially in different FS interneuron subtypes. Because basket and chandelier cells constitute the two main classes of PV FS interneurons that express the bulk of ErbB4 receptors, it would clearly be of interest and of importance to elucidate the differential functions that ErbB4 plays in development of PFC interneurons compared with hippocampal neurons.

Based primarily on the observations that ErbB4 colocalizes with and interacts with PSD-95 (Garcia et al., 2000; Huang et al., 2000 ) and its main expression in PV interneuronal somatodendritic areas (Yau et al., 2003; Vullhorst et al., 2009; Fazzari et al., 2010), three independent studies recently demonstrated that ErbB4 signaling plays an important role during the development of glutamatergic synapses on FS interneurons (Fazzari et al., 2010; Abe et al., 2011; Ting et al., 2011). Here, we provided further evidence clearly showing that in the mPFC, ErbB4 signaling mainly controls the final maturation of glutamatergic PN-FS basket cell connections (Fig. 8), but has little effect on the initial synapse formation (Fig. 7). This is in contrast to a previous study by Fazzari et al. (2010) who examined this at relatively early stages (P20) in the hippocampus and already found differences. Our results are supported by two previous in vitro studies (Li et al., 2007; Krivosheya et al., 2008), but we cannot exclude the possibility that, because the mPFC is among the last to mature, later than the hippocampus, initial synapse formation in the mPFC might not be finished at P16-P20. However, several previous investigations of the functions of ErbB4 signaling during cortical circuitry development focused mainly on the development of excitatory input to PNs (Gu et al., 2005; Li et al., 2007; Barros et al., 2009). Because ErbB4 receptors are expressed in subpopulations of GABAergic interneurons, but not in PNs, how then does the deletion of erbb4 in interneurons lead to alterations of excitatory synapses on PNs? One possible explanation is that excitatory synapses on PNs may be altered as a compensatory response to the GABAergic circuit change (Cooper and Koleske, 2011). In line with this possibility, early postnatal disruptions of glutamate transmission on PV FS interneurons generate schizophrenia-like phenotypes (Fuchs et al., 2007; Belforte et al., 2010; Korotkova et al., 2010).

Previous studies showed that ErbB4 is involved in acute regulation of activity-dependent FS $\rightarrow$ PN transmissions (Woo et al., 2007; Chen et al., 2010; Li et al., 2012b), and mice with a deletion of ErbB4 in PV interneurons exhibit brain hyper-excitability in a number of behavioral tests (Wen et al., 2010; Li et al., 2012b; Shamir et al., 2012; Tan et al., 2012). Here, we found that early deletion of ErbB4 signaling in GABAergic forebrain neurons during the embryonic period also decreases GABAergic FS-PN transmissions in an activity-dependent manner (Fig. 9; Table 1) and increases PN neuronal activity. A decrease in excitatory innerva- tions on PV FS interneurons would lead to an increase in neuronal activity via homeostatic mechanisms (Turrigiano and Nelson, 2004), which however, was decreased in KO mice (Fig. 9), suggesting a lack of compensatory homeostasis. Furthermore, the decrease of glutamatergic synapses on FS basket cells should not be due to an increase in synaptic elimination that results from the lower activity level after ErbB4 deletion because the number of GABAergic synapses on FS interneurons is unaltered (Fig. 5), further suggesting that the homeostatic synaptic scaling rule is not applied to these excitatory synapses on the inhibitory neurons. Thus, we speculate that there exist distinct regulatory mechanisms for ErbB4 signaling on glutamatergic synapse maturation and excitability of FS neurons; the underlying mechanisms require further research.

Overall, we demonstrated that in the mouse MPFC in vivo, it is the development of glutamatergic synapses, but not GABAergic synapses by PV FS basket cells that depends on ErbB4 signaling. More interestingly, ErbB4 signaling mainly controls the final maturation rather than the initial formation of glutamatergic synapses on FS basket cells. In addition, knock-out of ErbB4 leads to a reduction in the level of activity-dependent GABAergic FS-PN transmission, thus decreasing inhibition mediated by FS interneurons, followed by an increase in PN neuronal activity. The disruption of excitation-inhibition balance during critical developmental periods, such as adolescence, may underlie the etiology of neuropsychiatric disorders such as schizophrenia (Lewis and Gonzalez-Burgos, 2008; Yizhar et al., 2011). A better understanding of the roles ErbB4 plays during development should shed more light on the pathogenesis of neuropsychiatric disorders.

\section{References}

Abe Y, Namba H, Kato T, Iwakura Y, Nawa H (2011) Neuregulin-1 signals from the periphery regulate AMPA receptor sensitivity and expression in GABAergic interneurons in developing neocortex. J Neurosci 31:56995709. CrossRef Medline

Barros CS, Calabrese B, Chamero P, Roberts AJ, Korzus E, Lloyd K, Stowers L, Mayford M, Halpain S, Müller U (2009) Impaired maturation of dendritic spines without disorganization of cortical cell layers in mice lacking NRG1/ErbB signaling in the central nervous system. Proc Natl Acad Sci U S A 106:4507-4512. CrossRef Medline

Belforte JE, Zsiros V, Sklar ER, Jiang Z, Yu G, Li Y, Quinlan EM, Nakazawa K (2010) Postnatal NMDA receptor ablation in corticolimbic interneurons confers schizophrenia-like phenotypes. Nat Neurosci 13:76-83. CrossRef Medline

Bennett MV, Zukin RS (2004) Electrical coupling and neuronal synchronization in the mammalian brain. Neuron 41:495-511. CrossRef Medline

Callicott JH, Mattay VS, Verchinski BA, Marenco S, Egan MF, Weinberger DR (2003) Complexity of prefrontal cortical dysfunction in schizophrenia: more than up or down. Am J Psychiatry 160:2209-2215. CrossRef Medline

Chattopadhyaya B, Di Cristo G, Higashiyama H, Knott GW, Kuhlman SJ, Welker E, Huang ZJ (2004) Experience and activity-dependent maturation of perisomatic GABAergic innervation in primary visual cortex during a postnatal critical period. J Neurosci 24:9598-9611. CrossRef Medline

Chen YJ, Zhang M, Yin DM, Wen L, Ting A, Wang P, Lu YS, Zhu XH, Li SJ, Wu CY, Wang XM, Lai C, Xiong WC, Mei L, Gao TM (2010) ErbB4 in parvalbumin-positive interneurons is critical for neuregulin 1 regulation of long-term potentiation. Proc Natl Acad Sci U S A 107:21818-21823. CrossRef Medline

Cooper MA, Koleske AJ (2011) ErbB4 localization to interneurons: clearer insights into schizophrenia pathology. Biol Psychiatry 70:602-603. CrossRef Medline

Fazzari P, Paternain AV, Valiente M, Pla R, Luján R, Lloyd K, Lerma J, Marín O, Rico B (2010) Control of cortical GABA circuitry development by Nrg1 and ErbB4 signalling. Nature 464:1376-1380. CrossRef Medline

Fisahn A, Neddens J, Yan L, Buonanno A (2009) Neuregulin-1 modulates 
hippocampal gamma oscillations: implications for schizophrenia. Cereb Cortex 19:612-618. CrossRef Medline

Flames N, Long JE, Garratt AN, Fischer TM, Gassmann M, Birchmeier C, Lai C, Rubenstein JL, Marín O (2004) Short- and long-range attraction of cortical GABAergic interneurons by neuregulin-1. Neuron 44:251-261. CrossRef Medline

Fuchs EC, Zivkovic AR, Cunningham MO, Middleton S, Lebeau FE, Bannerman DM, Rozov A, Whittington MA, Traub RD, Rawlins JN, Monyer H (2007) Recruitment of parvalbumin-positive interneurons determines hippocampal function and associated behavior. Neuron 53:591-604. CrossRef Medline

Gajendran N, Kapfhammer JP, Lain E, Canepari M, Vogt K, Wisden W, Brenner HR (2009) Neuregulin signaling is dispensable for NMDA- and GABA(A)-receptor expression in the cerebellum in vivo. J Neurosci 29: 2404-2413. CrossRef Medline

Garcia RA, Vasudevan K, Buonanno A (2000) The neuregulin receptor ErbB-4 interacts with PDZ-containing proteins at neuronal synapses. Proc Natl Acad Sci U S A 97:3596-3601. CrossRef Medline

Gu Z, Jiang Q, Fu AK, Ip NY, Yan Z (2005) Regulation of NMDA receptors by neuregulin signaling in prefrontal cortex. J Neurosci 25:4974-4984. CrossRef Medline

Huang YZ, Won S, Ali DW, Wang Q, Tanowitz M, Du QS, Pelkey KA, Yang DJ, Xiong WC, Salter MW, Mei L (2000) Regulation of neuregulin signaling by PSD-95 interacting with ErbB4 at CNS synapses. Neuron 26: 443-455. CrossRef Medline

Kawaguchi Y (1995) Physiological subgroups of nonpyramidal cells with specific morphological characteristics in layer II/III of rat frontal cortex. J Neurosci 15:2638-2655. Medline

Kawaguchi Y, Kubota Y (1997) GABAergic cell subtypes and their synaptic connections in rat frontal cortex. Cereb Cortex 7:476-486. CrossRef Medline

Korotkova T, Fuchs EC, Ponomarenko A, von Engelhardt J, Monyer H (2010) NMDA receptor ablation on parvalbumin-positive interneurons impairs hippocampal synchrony, spatial representations, and working memory. Neuron 68:557-569. CrossRef Medline

Krivosheya D, Tapia L, Levinson JN, Huang K, Kang Y, Hines R, Ting AK, Craig AM, Mei L, Bamji SX, El-Husseini A (2008) ErbB4-neuregulin signaling modulates synapse development and dendritic arborization through distinct mechanisms. J Biol Chem 283:32944-32956. CrossRef Medline

Lewis DA, González-Burgos G (2008) Neuroplasticity of neocortical circuits in schizophrenia. Neuropsychopharmacology 33:141-165. CrossRef Medline

Lewis DA, Hashimoto T, Volk DW (2005) Cortical inhibitory neurons and schizophrenia. Nat Rev Neurosci 6:312-324. CrossRef Medline

Li B, Woo RS, Mei L, Malinow R (2007) The neuregulin-1 receptor erbB4 controls glutamatergic synapse maturation and plasticity. Neuron 54: 583-597. CrossRef Medline

Li H, Chou SJ, Hamasaki T, Perez-Garcia CG, O’Leary DD (2012a) Neuregulin repellent signaling via ErbB4 restricts GABAergic interneurons to migratory paths from ganglionic eminence to cortical destinations. Neural Dev 7:10. CrossRef Medline

Li KX, Lu YM, Xu ZH, Zhang J, Zhu JM, Zhang JM, Cao SX, Chen XJ, Chen Z, Luo JH, Duan S, Li XM (2012b) Neuregulin 1 regulates excitability of fast-spiking neurons through Kv1.1 and acts in epilepsy. Nat Neurosci 15:267-273. CrossRef Medline

Marín O (2012) Interneuron dysfunction in psychiatric disorders. Nat Rev Neurosci 13:107-120. CrossRef Medline

Mei L, Xiong WC (2008) Neuregulin 1 in neural development, synaptic plasticity and schizophrenia. Nat Rev Neurosci 9:437-452. CrossRef Medline

Neddens J, Buonanno A (2010) Selective populations of hippocampal interneurons express ErbB4 and their number and distribution is altered in ErbB4 knockout mice. Hippocampus 20:724-744. CrossRef Medline

Neddens J, Fish KN, Tricoire L, Vullhorst D, Shamir A, Chung W, Lewis DA,
McBain CJ, Buonanno A (2011) Conserved interneuron-specific ErbB4 expression in frontal cortex of rodents, monkeys, and humans: implications for schizophrenia. Biol Psychiatry 70:636-645. CrossRef Medline

Rio C, Rieff HI, Qi P, Khurana TS, Corfas G (1997) Neuregulin and erbB receptors play a critical role in neuronal migration. Neuron 19:39-50. CrossRef Medline

Shamir A, Kwon OB, Karavanova I, Vullhorst D, Leiva-Salcedo E, Janssen MJ, Buonanno A (2012) The importance of the NRG-1/ErbB4 pathway for synaptic plasticity and behaviors associated with psychiatric disorders. J Neurosci 32:2988-2997. CrossRef Medline

Shimamura K, Martinez S, Puelles L, Rubenstein JL (1997) Patterns of gene expression in the neural plate and neural tube subdivide the embryonic forebrain into transverse and longitudinal domains. Dev Neurosci 19:8896. CrossRef Medline

Silberberg G, Darvasi A, Pinkas-Kramarski R, Navon R (2006) The involvement of ErbB4 with schizophrenia: association and expression studies. Am J Med Genet B Neuropsychiatr Genet 141B:142-148. CrossRef Medline

Soltesz I, Smetters DK, Mody I (1995) Tonic inhibition originates from synapses close to the soma. Neuron 14:1273-1283. CrossRef Medline

Tan GH, Liu YY, Hu XL, Yin DM, Mei L, Xiong ZQ (2012) Neuregulin 1 represses limbic epileptogenesis through ErbB4 in parvalbuminexpressing interneurons. Nat Neurosci 15:258-266. CrossRef Medline

Taniguchi H, Lu J, Huang ZJ (2013) The spatial and temporal origin of chandelier cells in mouse neocortex. Science 339:70-74. CrossRef Medline

Ting AK, Chen Y, Wen L, Yin DM, Shen C, Tao Y, Liu X, Xiong WC, Mei L (2011) Neuregulin 1 promotes excitatory synapse development and function in GABAergic interneurons. J Neurosci 31:15-25. CrossRef Medline

Turrigiano GG, Nelson SB (2004) Homeostatic plasticity in the developing nervous system. Nat Rev Neurosci 5:97-107. CrossRef Medline

Vullhorst D, Neddens J, Karavanova I, Tricoire L, Petralia RS, McBain CJ, Buonanno A (2009) Selective expression of ErbB4 in interneurons, but not pyramidal cells, of the rodent hippocampus. J Neurosci 29:1225512264. CrossRef Medline

Wen L, Lu YS, Zhu XH, Li XM, Woo RS, Chen YJ, Yin DM, Lai C, Terry AV Jr, Vazdarjanova A, Xiong WC, Mei L (2010) Neuregulin 1 regulates pyramidal neuron activity via ErbB4 in parvalbumin-positive interneurons. Proc Natl Acad Sci U S A 107:1211-1216. CrossRef Medline

Williams SM, Goldman-Rakic PS, Leranth C (1992) The synaptology of parvalbumin-immunoreactive neurons in the primate prefrontal cortex. J Comp Neurol 320:353-369. CrossRef Medline

Woo RS, Li XM, Tao Y, Carpenter-Hyland E, Huang YZ, Weber J, Neiswender H, Dong XP, Wu J, Gassmann M, Lai C, Xiong WC, Gao TM, Mei L (2007) Neuregulin-1 enhances depolarization-induced GABA release. Neuron 54:599-610. CrossRef Medline

Yang JM, Zhang J, Yu YQ, Duan S, Li XM (2012) Postnatal development of 2 microcircuits involving fast-spiking interneurons in the mouse prefrontal cortex. Cereb Cortex, in press. CrossRef Medline

Yau HJ, Wang HF, Lai C, Liu FC (2003) Neural development of the neuregulin receptor ErbB4 in the cerebral cortex and the hippocampus: preferential expression by interneurons tangentially migrating from the ganglionic eminences. Cereb Cortex 13:252-264. CrossRef Medline

Yizhar O, Fenno LE, Prigge M, Schneider F, Davidson TJ, O'Shea DJ, Sohal VS, Goshen I, Finkelstein J, Paz JT, Stehfest K, Fudim R, Ramakrishnan C, Huguenard JR, Hegemann P, Deisseroth K (2011) Neocortical excitation/inhibition balance in information processing and social dysfunction. Nature 477:171-178. CrossRef Medline

Zerucha T, Stühmer T, Hatch G, Park BK, Long Q, Yu G, Gambarotta A, Schultz JR, Rubenstein JL, Ekker M (2000) A highly conserved enhancer in the Dlx5/Dlx6 intergenic region is the site of cross-regulatory interactions between Dlx genes in the embryonic forebrain. J Neurosci 20:709721. Medline 